\title{
Rethinking Symbolic Racism: Evidence of Attribution Bias
}

\author{
Brad T. Gomez University of South Carolina \\ J. Matthew Wilson Southern Methodist University
}

\begin{abstract}
This paper demonstrates that cognitive tendencies related to political sophistication produce an attribution bias in the widely accepted symbolic racism scale. When this bias is controlled statistically, the effect of symbolic racism on racial policy attitudes is greatly diminished. Our theory posits that high sophisticates tend to make global/distal attributions, allowing them to associate racial inequality with broader sociopolitical causes. Less sophisticated individuals, conversely, tend to make local/proximal attributions, thus biasing them against ascribing responsibility systemically. Consequently, less sophisticated individuals tend to be classified as intolerant by the symbolic racism scale, even when controlling for factors such as ideology and anti-black affect.
\end{abstract}

$\Lambda$ critical component of whites' attitudes toward blacks is their beliefs about the causes of poverty in the black community and social inequality between the races more generally. ${ }^{1}$ These attitudes contribute significantly to whites' positions on public policies geared to ameliorate racial inequities, such as affirmative action (e.g., Hughes and Tuch 2000; Sniderman et al. 1986) and welfare (Gilens 1996). For some whites, the observed disparity between the races is a function of systemic causes, such as unequal educational and job opportunities or a legacy of discrimination ("structuralist attributions"; Feagin 1972). Conversely, other whites view racial disparities as a product of traits stereotypically associated with individual African Americans, such as a poor work ethic or a lack of intelligence ("individualistic attributions").

Previous research-in political science and other disciplines-has shown that, while both structuralist and individualistic attributions contribute to whites' racial policy attitudes, the former, though less common, play a more powerful role than the latter in predicting these attitudes (e.g., Hunt 1996; Kluegel and Smith 1986). Individuals who accept structuralist explanations for black poverty are more supportive of policies intended to assist blacks. Yet many questions remain unanswered about how structuralist and individualistic attributions themselves are formed. Some scholars, most notably Kluegel and Smith (1986), provide a sociological explanation, arguing that socioeconomic status strongly shapes individuals' explanations for poverty. By this account, the difference in attribution patterns may merely be a function of social class - the "haves" think the "have-nots" are lazy, while the latter think the former benefit disproportionately from social arrangements. Perhaps the divergence runs deeper, stemming from psychological differences inherent in the construction of causality. After all, interpersonal attributions are a fundamental component of social cognition (Fiske and Taylor 1991). This raises a key question: Does an individual's cognitive complexity increase his or her likelihood of making certain causal linkages, while mitigating the perceived importance of competing explanatory factors?

In this paper, we advance a theory of heterogeneous attribution, wherein individual differences in cognitive sophistication within a relevant domain condition the tendency to attribute responsibility to proximal (individualistic) or more global (structuralist) causes. We argue that individuals low in political sophistication, controlling for other factors

${ }^{1}$ Blacks comprise a disproportionate share of the poor in the United States, about $25 \%$, and are more than twice as likely as whites to live in poverty (U.S. Bureau of the Census 2002).

The Journal of Politics, Vol. 68, No. 3, August 2006, pp. 611-625 
such as ideology and racial animus, are unlikely to attribute responsibility for racial inequality to social causes. Given a more limited comprehension of the sociopolitical world, low sophisticates have a decreased propensity to construct broad social explanations and, correspondingly, to devise/ acknowledge social solutions. High political sophisticates, who are more likely to understand the complexity of the sociopolitical world, do have the cognitive capacity - a large store of integrated political referents in associative memory (e.g., McGraw and Pinney 1990; Tetlock 1995)—to make structuralist attributions, and are thus more likely to do so. In short, we contend that variation in whites' attributions regarding the causes of black poverty and social disadvantage is a function not simply of economic selfinterest and/or racial prejudice, but also of cognitive style.

While the cognitive foundations of attributions for racial inequality are in themselves important, our work also has ramifications for the widely used and often debated concept of symbolic racism. Recent work by Tarman and Sears (2005) demonstrates that the factorial structure of the traditional symbolic racism scale is best explained by the structuralist and individualist attribution concepts. Consequently, we reexamine symbolic racism and its effect on policy attitudes in light of the theory of heterogeneous attribution. Simply put, we argue that individual responses to the battery of survey items generally used to create the symbolic racism measure may be biased by cognitive ability and shaped by factors completely independent of the underlying racial animus that the scale seeks to capture. This attribution bias affects placement on the symbolic racism scale, since those who respond positively to the structuralist items are considered low in symbolic racism, while individualist respondents are scored high. If the theory of heterogeneous attribution is accurate, individuals low in political sophistication may be biased against accepting the structuralist items and in favor of the individualist ones for reasons wholly apart from racial hostility or ideology. Thus, low sophisticates, all things equal, run a greater risk of being incorrectly classified as "symbolic racists." After demonstrating an empirical relationship between political sophistication and symbolic racism, we reevaluate the latter concept's impact on racial policy attitudes. We propose that an "errors in variables" correction be used when symbolic racism is employed as an independent variable in models, and show that the effect of symbolic racism as an explanation for racial policy attitudes may be grossly exaggerated.

\section{The Attributional Foundations of Symbolic Racism}

One of the core tenets in the study of white America's attitudes toward race and racial policy is the concept of "symbolic racism." Originating with the work of Sears and Kinder (1971), symbolic racism is meant to describe whites' animus toward blacks in its contemporary guise. As opposed to the overt racism of the Jim Crow era, which Sears and Kinder argue was repudiated and largely displaced by the end of the 1960s, symbolic racism reflects a subtler form of intolerance. The theory is built on four propositions (Kinder and Sanders 1996; Sears 1988). First, the civil rights movement and end to legal segregation precipitated a decline in the social acceptability of older forms of racism. Second, this decline in overtly racist attitudes did not represent a true proportional reduction in whites' antipathy toward blacks. White racism and racial stereotyping remain, but they are hidden from public view (and, consequently, poorly measured by survey instruments). Third, blacks are perceived by racially intolerant whites to violate traditional American values, such as the Protestant work ethic. Finally, racial prejudice often manifests itself as resentment; blacks are perceived as demanding and receiving too much from government, making it difficult for whites to receive fair treatment.

Symbolic racism has been shown to be a powerful predictor of whites' opposition to racial policies and black political candidates, in some cases exerting a larger effect than party identification, political ideology, adherence to the value of individualism, and direct racial threat (e.g., Kinder and Sanders 1996; Kinder and Sears 1981). Yet, despite these findings, the symbolic racism concept has drawn its share of critics.

In a recent article reevaluating the conceptualization and measurement of symbolic racism, Tarman and Sears focus on four central critiques of the construct: "symbolic racism (1) has been conceptualized and measured inconsistently over time, (2) may not be a single, internally consistent, and coherent belief system, (3) may generate artifactually strong associations with racial policy preferences because of content overlap between measures of the independent and dependent variables, and (4) is not a distinctive belief system in its own right, but simply reflects various other familiar constructs" $(2005,732)$. The second and fourth of these critiques are clearly related and, for our purposes, the most compelling.

In addressing the internal coherence of symbolic racism, Tarman and Sears examine the dimensional 
structure of survey items frequently used to measure it. What the authors find is that-at least on point two-their critics are correct: "the pure one-factor model [of symbolic racism] is of borderline acceptability" (2005, 741). The authors demonstrate that a two-factor model best represents the underlying dimensional structure of symbolic racism. Importantly, they assert that these latent dimensions reflect individualistic attributions and structuralist attributions for black inequality $(2005,742-48){ }^{2}$

Affirmation of symbolic racism's attribution underpinnings and empirical validation of its individualist and structuralist dimensions may not seem especially problematic for the concept. Indeed, Tarman and Sears contend that "the difference between these two factors is so slight that they seem best interpreted as two quite similar variants of the same underlying psychological construct" $(2005,747)$. We believe, however, that this contention minimizes the potential behavioral consequences of symbolic racism's attributional structure. Social psychologists have long argued that, for various reasons, different people have different propensities for making individualistic and structuralist attributions. Moreover, research has shown that structuralist attributions are more closely associated with support for race-based public policies than are individualistic ones (Kluegel and Smith 1986). If the evidence regarding structuralist attributions and racial policy attitudes is accurate, then the link between symbolic racism and racial policy may be more a function of general cognitive tendencies than of racial animus. If symbolic racism is most accurately perceived as an attribution construct (as Tarman and Sears concede), then we must consider the possibility that variation in the scale can be explained, at least in part, by individual differences in attribution psychology.

\section{Causal Attributions and Racial Inequality}

According to Feagin (1972), individuals attribute three main causes for poverty: deficiencies of poor people (individualistic attributions), societal barriers (structuralist attributions), and bad luck (fatalistic

${ }^{2}$ Our own factor analysis produces results consistent with Tarman and Sears' findings. Additionally, we go a step further. Using a multisample confirmatory factor analysis, we demonstrate that the two-factor structure exists for both high and low sophisticates and that the factor correlations between individualistic and structuralist attributions are not significantly different between the two groups. Results are available from the authors or via the JOP web site (http://journalofpolitics.org/articles.html). attributions). ${ }^{3}$ Among these, the most commonly cited explanation is the individualistic one. People are most likely to blame economic inequality on the real or imagined characteristics of the poor themselves, like lack of work ethic or ability. Further research shows that individualistic explanations of social inequality are not simply a by-product of racial differences or racial animus. Hughes and Tuch (2000) provide evidence that whites, blacks, Asian-Americans, and Latinos all tend toward individualistic attributions, whether one is discussing black poverty or the misfortunes of any other group.

It has been hypothesized that the tendency to choose individualistic over structuralist attributions is rooted in economic self-interest. Kluegel and Smith (1986) identify a propensity among people of higher socioeconomic status to focus primarily on individualistic attributions. Perhaps this results from selfreflection; high SES individuals might assume that their impoverished fellow citizens lack important qualities that they see in themselves. Whatever the reason, this SES effect, like the general predisposition toward individualistic attributions, does not appear to be restricted to whites. Hunt (1996) provides evidence that African Americans and Latinos are actually more apt to provide individualistic attributions than are whites. Moreover, within these groups, Hunt reports that systematic differences related to SES also exist, providing further evidence in support of the selfinterest hypothesis. ${ }^{4}$

An additional distinction between individualistic and structuralist attributions remains, one relating not to the causes of these ascriptions but to their relationship to policy attitudes. Hughes and Tuch (2000), among others, show that structuralist attributions are significant predictors of support for race-based public policies, such as affirmative action and welfare. Those who see society and government as the source of black social disadvantage are more inclined to favor social and governmental solutions. Indeed, these authors

${ }^{3}$ Fatalistic explanations are rarely invoked and thus will not be considered in this paper.

${ }^{4}$ One should not assume that the individualistic and structuralist explanations are necessarily orthogonal. Kluegel (1990) notes that individuals frequently create explanations for economic inequality from both individualistic and structuralist attributions. Interestingly, this "dual consciousness" exists even among the poor (Kluegel and Smith 1986) and may be more likely among minority groups. Hughes and Tuch, for instance, argue that "members of minority groups are more likely than whites to experience a 'dual consciousness,' simultaneously subscribing to both structuralist beliefs (by virtue of group identification) and individualistic beliefs (as a result of acculturation to dominant American values that are relatively stable)" $(2000,167)$. 
demonstrate the power of system blame, indicating that "structural attributions increase support for racetargeted policies across ethnic groups [whites, blacks, Asian-Americans, and Latinos] regardless of which group is the focus of attributions" $(2000,188)$. Thus, it is important to note, the relationship between structuralist attributions and support for policies targeting racial disparities (or, conversely, the relationship between individualistic attributions and opposition to these policies) does not necessarily stem from differing levels of racial tolerance. In theory, a linkage between the attribution and policy may simply reflect a necessary condition for support: to see government as an appropriate remedy, one must first view society as a cause of the problem. ${ }^{5}$

\section{The Theory of Heterogeneous Attribution}

That some individuals make individualistic attributions, while others offer structuralist attributions, and still others attribute responsibility to both, shows the need for further theorizing on this important public opinion puzzle, especially given the role of attribution in predicting policy attitudes. Class and ethnicity provide two plausible bases for these alternative understandings of racial inequality. However, the possibility that individuals might differ systematically in their attribution patterns due to cognitive differences has not been examined. We believe that this consideration may provide significant insights into the construction of social stratification beliefs generally and into the meaning of the symbolic racism scale specifically.

In recent work centering on ascriptions of causality (Gomez and Wilson 2001, 2003, 2006b), we articulate a "theory of heterogeneous attribution" as an explanation for how citizens at various levels of cognitive complexity assign responsibility for sociopolitical phenomena. Following Sniderman (1993), among others, we assume that people should not be treated as monolithic; that is, individuals should not be thought to respond uniformly to cognitive stimuli. Rather, we propose that systematic variation in indi-

${ }^{5}$ This argument is somewhat consistent with "political models" of racial policy attitudes put forth by Sniderman and colleagues (e.g., Sniderman and Carmines 1997; Sniderman and Piazza 1993). However, while the political model might view structuralist attributions as necessary conditions for support for government policy, they clearly are not sufficient. The political model asserts that support for racial policies is also a product of ideology and the policy alternatives on the agenda. viduals' ability to make causal associations is conditioned by their levels of cognitive sophistication in the domain of politics (i.e., political sophistication). We argue that the breadth and depth of an individual's political knowledge largely determines his ability to make "local" or "global" attributions for sociopolitical phenomena. Thus, a person's ability to ascribe credit or blame to individual versus systemic factors is a function of his capacity to make associative linkages between political information in different spheres. ${ }^{6}$

Attribution psychology suggests that causal attribution is affected both by the characteristics of the problem confronting the individual and by the characteristics of the person trying to work through it. As Hilton and Slugoski (1986) put it, the attribution process is sensitive to the individual's base level of information/knowledge and motivation toward the task. In other words, to identify a causal relationship, the individual must have knowledge of possible causes and be motivated to puzzle through the causal linkage. As such, a sophisticated understanding of the subject (domain) at hand would seem to condition the individual's capacity to make attributions. Given that "modern racism" is so intrinsically tied to politics, we believe that individuals at varying levels of political sophistication will differ in the way they make attributions regarding race in modern America. ${ }^{7}$

Following Luskin (1987), Sniderman (1993), and our own previous work (Gomez and Wilson 2001, 2003, 2006b), we argue that individuals with differing levels of political sophistication vary in their ability to make associative linkages between problems and their sources. Political sophistication is a two-fold concept incorporating the individual's levels of political awareness and cognitive integration (Luskin 1987). ${ }^{8}$ It

\footnotetext{
${ }^{6}$ As Iyengar asserts, "attributions of responsibility are critical ingredients of social knowledge" $(1989,879)$. As a means of inference, attributions have been shown to have powerful effects on an individual's attitude toward the self, emotional arousal, and interpersonal evaluations (e.g., Fiske and Taylor 1991; Petty and Cacioppo 1996). Indeed, the capacity of causal attributions to frame interpersonal evaluations is fundamental to political opinionation, particularly assessments of political leaders (Iyengar 1989) and vote choice (e.g., Lau and Sears 1981).
}

${ }^{7}$ Race in America has always been a salient sociopolitical issue, from arguments in the early republic about slavery and representation, through debates over segregation and anti-miscegenation laws, up to the present day. Almost all of the symbolic ways in which modern racism is said to manifest itself reside in the political domain: affirmative action, welfare, busing, etc. Thus, we feel comfortable in saying that racial attributions are conditioned by political sophistication.

${ }^{8}$ As Sniderman, Brody, and Tetlock argue: "[P] $]$ olitical sophistication is a 'bundle' concept. It packs together related, if distinguish- 
should not be viewed simply as a summary scale of political interest. Rather, individuals at various levels of political sophistication cognitively engage the political world in different ways, using heterogeneous decision rules in processing political information and making political choices. Far from maximizing the consistency of belief system elements across the board, individuals with differing levels of political sophistication seek congruence selectively (Sniderman, Brody, and Tetlock 1991). In contrast to Converse's (1964) model of the political belief system, the sophistication model suggests that it is the least sophisticated individuals, not the most, who attempt to maximize proximal consistency among belief elements, bringing closely related political information into congruence. Alternatively, highly sophisticated individuals seek distal consistency in their political belief systems. These political sophisticates recognize and evaluate the more abstract elements of the political world and seek congruence between newly obtained information and more distant components of their belief systems, such as their ideologies.

With regard to beliefs about the causes of poverty and social inequality more generally, the theory of heterogeneous attribution suggests several hypotheses. As our previous work (Gomez and Wilson 2001, 2003, $2006 \mathrm{~b}$ ) demonstrates in the nonracial domain of economic voting, less politically sophisticated individuals tend to focus causal attributions on the most obvious, proximal actors (which in the case of racial disparities would be African Americans themselves) or events. ${ }^{9}$ Thus, the theory asserts that individuals at low levels of sophistication will find it cognitively difficult to

able, properties including a tendency to pay close attention to politics, to have ready at hand banks of information about it, to understand multiple arguments for and against particular issue positions, and to recognize interrelationships among those arguments" $(1991,21)$

${ }^{9}$ Readers familiar with the broader attribution literature (e.g., Heider 1958; Jones and Davis 1965; Kelley 1967) might recognize that under certain conditions the theory of heterogeneous attribution mimics the "fundamental attribution error" - "the tendency to attribute behavior exclusively to the actor's dispositions and to ignore powerful situational determinants of the behavior" (Nesbitt and Ross 1980, 31). This mimicry occurs when low sophisticates attribute responsibility to an individual (or class of individuals) instead of systemic factors. Our present case of racial attributions is an example of the two theories overlapping. However, the theory of heterogeneous attribution does not restrict itself to individual versus systemic cases. The "obvious," proximal attribution in some cases might be to a major event or even to a highly salient systemic cause. For example, low sophisticates might blame the economic recession of 2001-2002 exclusively on the terrorist attacks of September 11, 2001. Clearly, this is not an individual attribution, so this case would not correspond with the fundamental attribution error. associate the condition of individuals in poverty with broad societal forces. To do so, one must at some level recognize the capacity of social, political, and economic factors to be systematically biased against a segment of the population. We believe that for many individuals at lower levels of political sophistication this is a difficult cognitive task. Consequently, low sophisticates will be more likely to rely on less distal attributions and associate the causes of poverty and social inequality with proximal characteristics of a disadvantaged group. Conversely, we believe that high sophisticates should be more likely to possess the level of cognitive integration required to understand the interrelationship of more global social phenomena (Tetlock 1995). Thus, two primary attribution hypotheses follow:

1) Individuals at low levels of political sophistication are more likely to make individualistic attributions and should be systematically biased against making structuralist attributions.

2) Individuals high in political sophistication are more likely to make structuralist attributions, though they may also make individualistic ones.

As a result of these hypotheses and Tarman and Sears' determination that symbolic racism is composed primarily of individualistic and structuralist attribution dimensions, a corollary to Hypothesis Two can be asserted:

Corollary: Individuals at high levels of political sophistication, ceteris paribus, are more likely to score low on the symbolic racism scale. ${ }^{10}$

Finally, we also believe that the extent to which the relationship between symbolic racism and racial policy attitudes reflects racial animus may be exaggerated. We expect the relationship between the two variables to be a function of an attributional style that varies in accordance with the theory of heterogeneous attribution. Consequently, we propose a third and final hypothesis:

3) Accounting for political sophistication will significantly attenuate the link between symbolic racism and racial policy attitudes.

Importantly, we should stress that these hypotheses are rooted in cognitive differences, not value orientations. Thus, they should survive controls for any differences in ideology, individualism, egalitarianism, and

\footnotetext{
${ }^{10}$ This corollary hypothesis assumes that symbolic racism is coded in its traditional manner.
} 
anti-black affect that may exist between high and low sophisticates.

\section{Data and Method}

Our examination of political sophistication and American racial attitudes draws on data from the 1986 and 2000 American National Election Studies. ${ }^{11}$ These studies contain items that allow us to measure several key concepts: individual political sophistication, symbolic racism, and racialized policy attitudes. The nowstandard symbolic racism questions were introduced in the NES in the early 1980s, and the NES political knowledge battery dates from several years later. The 1986 study is the first one in which both are present. Both sets of items have been repeated (with some variation) in most of the subsequent studies. This allows us to conduct parallel analyses in both 1986 and 2000, the earliest and most recent years for which the necessary data are available. Results consistent across both of these periods may reasonably be viewed as generalizable, not an artifact of ephemeral circumstances in any one electoral cycle.

Operationally, we encounter several important choices regarding how best to measure both racial attitudes and political sophistication. Though originally constructed from an extensive battery of questions, the symbolic racism scale is now typically built from four items (Kinder and Sanders 1996). Respondents are presented statements and asked whether they agree strongly, agree somewhat, neither agree nor disagree, disagree somewhat, or disagree strongly. We have taken these responses and recoded them to run from least to most "racist." They are added and rescaled to range from 0 (least symbolic racism) to 1 (most symbolic racism).

The individual items of the symbolic racism scale differ in ways that allow for interesting tests of our hypotheses regarding political sophistication and causal attribution. Two of the items clearly tap individualistic attributions for racial disparities in American society, blaming African Americans' failure to strive for advancement and to work hard enough. They are as follows:

1). "Irish, Italians, Jews, and many other minorities overcame prejudice and worked their way up.

\footnotetext{
${ }^{11}$ These analyses are based on data compiled by the Inter-University Consortium for Political and Social Research. The original collector of the data, ICPSR, and the relevant funding agency bear no responsibility for uses of this collection or for inferences based upon such uses.
}

Blacks should do the same without any special favors." 12

2). "It's really a matter of some people not trying hard enough; if blacks would only try harder they could be just as well off as whites."

The other two items, conversely, capture structuralist attributions for black social disadvantage, placing the locus of causality outside the individuals directly involved. These statements cast individual African Americans as victims of forces beyond their control. ${ }^{13}$ They are as follows:

1). "Over the past few years, blacks have gotten less than they deserve."

2). "Generations of slavery and discrimination have created conditions that make it difficult for blacks to work their way out of the lower class."

The differences between these questions allow us to test our hypothesis that less sophisticated individuals score higher on symbolic racism because of their greater tendency to make localized, individual-level attributions and their tendency to avoid global or distal ascriptions of causality.

The operationalization of political sophistication has long been an issue of concern (e.g., Luskin 1987). Conceptually, we wish to capture some mix of knowledge and awareness in the domain of politics and to assess the level of cognitive complexity with which an individual engages social and political phenomena. ${ }^{14}$ To that end, we construct an additive index based on eight factual queries in the NES (rescaled to range from 0 to 1). For 1986, these include the offices held by Vice President George Bush, House Speaker Tip O’Neill, Senate Majority Leader Bob Dole, Defense Secretary Caspar Weinberger, Federal Reserve Chairman Paul Volker, and Chief Justice William Rehnquist.

\footnotetext{
${ }^{12}$ This symbolic racism item is also found in The Washington Post, the Kaiser Family Foundation, and Harvard (1995) study of racial attitudes called the "Four Americas Survey." In a supplemental analysis (available from the authors or via the JOP web site), we use these data to further validate our claims. While this study does not include general political information items, it does measure factual knowledge specific to the domain of race. As a result, we are able, at least in part, to examine the robustness of our theoretical approach using two substantially different measurements of political sophistication.
}

${ }^{13}$ Tarman and Sears' (2005) factor analysis and LISREL model confirm that the symbolic racism items do in fact break down along individualist and structuralist dimensions, just as we contend here.

${ }^{14}$ This conception of sophistication is in keeping with Sniderman, Brody, and Tetlock's (1991) "bundle concept," combining elements of knowledge, awareness, and complexity of thought. 
In addition, respondents are queried about the majority parties in the House and Senate. ${ }^{15}$ In 2000, the questions are similar. Respondents are asked to identify the offices held by Senate Majority Leader Trent Lott, Attorney General Janet Reno, British Prime Minister Tony Blair, and Chief Justice William Rehnquist, as well as the home states of presidential candidates George Bush and Al Gore. Finally, the questions about party control of House and Senate are repeated. ${ }^{16}$ Delli Carpini and Keeter $(1993,1996)$ provide support for this measurement approach, showing that these NES items create a valid and reliable measure of political sophistication (or political knowledge-they use the terms almost interchangeably). ${ }^{17}$ Moreover, they parallel very closely the political sophistication measures employed in our previous work (Gomez and Wilson 2001, 2003). Perhaps most importantly, in related work, we demonstrate that our measure is indeed a function of political interest and cognitive complexity-assessed using the Cacioppo et al. (1996) "need for cognition" scale (Gomez and Wilson 2006a).

\section{Models and Results}

Our analysis begins by examining the premise underlying all of our more specific claims: that political sophistication significantly decreases individuals' scores on the symbolic racism scale, even controlling for all of the standard predictors. For both 1986 and 2000, we construct OLS models of symbolic racism among whites. The dependent variable is an additive scale of responses to the four items discussed above. Strong agreement with the structuralist attributions is coded 0 and strong disagreement 4 , while the individualistic attributions are coded oppositely. In total, this

\footnotetext{
${ }^{15}$ The mean respondent score on the 1986 knowledge scale is .36 . The easiest item is the Bush identification ( $78 \%$ correct), while the most difficult item is the Dole identification (12\% correct). Principal components factor analysis reveals one common factor for the eight items (eigenvalue $=2.46$ ), and all variables load on the factor to a significant degree (at least .48).

${ }^{16}$ The mean respondent score on the 2000 knowledge scale is .46. The easiest item is the question about Bush's home state $(90 \%$ correct), while the most difficult item is the Lott identification (9\% correct). Principal components factor analysis reveals one common factor for the eight items (eigenvalue $=2.45$ ), and all variables load on the factor to a significant degree (at least .40).

${ }^{17}$ To capture greater variability in our sophistication measure, we rely upon an eight-item battery of knowledge questions. In their work, Delli Carpini and Keeter (1993) assert that five- and even three-item scales work equally well in measuring differences in political sophistication.
}

produces a 17-point range, rescaled to run from 0 to 1 (least to most "racist").

We employ a variety of independent variables that might plausibly shape individuals' explanations of African American social disadvantage. To begin, we include a race-of-interviewer term, assuming that whites might give more racially tolerant responses to black interviewers. ${ }^{18}$ We include a battery of demographic items, including gender, age, region (South), income, church attendance, and education. Of these, we have particularly strong expectations for region and education. Given the South's difficult racial history, we expect whites from that region to have somewhat less favorable attitudes toward African Americans, ceteris paribus, than whites in other parts of the country. More importantly, education should exert a powerful influence here, as scholars have consistently found that more educated people express more tolerant attitudes (e.g., McCloskey 1964; Prothro and Grigg 1960; Sniderman, Brody, and Tetlock 1991). In the domain of race, this could be for one or both of two reasons. First, education may expose individuals to more diverse people and perspectives, thus enhancing tolerance and acceptance of difference. More cynically, one might expect that education teaches people the "right" answers to questions about race, schooling them in political correctness rather than fostering sincere racial understanding. In either case, we expect a strong negative correlation between education and symbolic racism, but for socialization, not cognitive, reasons. It is thus essential to include both education and sophistication separately in the models. ${ }^{19}$

Beyond demographic measures, we incorporate a set of attitudinal items that have long been thought to do most of the "heavy lifting" in explaining individuals' symbolic racism scores (Kinder and Sanders 1996; Sears 1988). To begin, we include measures of partisanship and ideology, on the assumption that structuralist as opposed to individual explanations for social disadvantage are a hallmark of liberal Democ-

\footnotetext{
${ }^{18}$ In 1986, unfortunately, we are only able to identify "nonwhite" interviewers, as blacks, Asians, Latinos, and other minorities are all lumped together into this category. Thus, the "black interviewer" term should be viewed with some caution in analyses for that year.

${ }^{19}$ While education and political sophistication are clearly related, they are empirically much more distinct than one might believe. In the 1986 and 2000 NES, the two are correlated at about .4, not trivial, but not overwhelming either. For our cognitive hypotheses about attribution patterns, it is critical to demonstrate that political sophistication plays a strong role in reducing symbolic racism scores even after controlling for the powerful socializing effects of education.
} 
TABLe 1 OLS Models of Symbolic Racism Among Whites, ANES 1986 and 2000

\begin{tabular}{|c|c|c|c|c|}
\hline \multirow[b]{2}{*}{ Independent Variables } & \multicolumn{2}{|c|}{1986} & \multicolumn{2}{|c|}{2000} \\
\hline & Estimate & S.E. & Estimate & S.E. \\
\hline Constant & .726 & $.054^{\star \star}$ & .983 & $.046^{\star \star}$ \\
\hline Black Interviewer & .033 & .040 & -.006 & .033 \\
\hline Female & -.016 & .016 & -.018 & 015 \\
\hline Age & -.001 & .001 & .001 & .001 \\
\hline South & .061 & $.017^{\star \star}$ & .030 & $.015^{\star}$ \\
\hline Income & -.002 & .001 & .002 & .002 \\
\hline Church Attendance & -.007 & .005 & -.003 & .005 \\
\hline Education & -.028 & $.006^{\star \star}$ & -.026 & $.005^{\star \star}$ \\
\hline Party Identification (Dem) & .002 & .003 & -.002 & .004 \\
\hline Ideology (Liberal) & -.021 & $.007^{\star \star}$ & -.020 & $.005^{\star \star}$ \\
\hline Individualism & .295 & $.047^{\star \star}$ & .070 & $.023^{\star \star}$ \\
\hline Egalitarianism & -.244 & $.042^{\star \star}$ & -.427 & $.039^{\star \star}$ \\
\hline Anti-Black Affect & .002 & $.000^{\star \star}$ & .002 & $.000^{\star \star}$ \\
\hline Political Sophistication & -.164 & $.035^{\star \star}$ & -.123 & $.032^{\star \star}$ \\
\hline Adj. $R^{2}=$ & \multicolumn{2}{|c|}{$.356^{\star \star}$} & \multicolumn{2}{|c|}{$.366^{* *}$} \\
\hline $\mathrm{N}=$ & \multicolumn{2}{|c|}{649} & \multicolumn{2}{|c|}{775} \\
\hline
\end{tabular}

Source: American National Election Studies, 1986 and 2000.

${ }^{* *} p<.01$, one-tailed test.

${ }^{*} p<.05$, one-tailed test.

ratic thinking. More importantly, following key theorists in the symbolic racism debate (Sears, Henry, and Kosterman 2000; Sniderman and Hagen 1985), as well as the seminal work by Feldman (1988; see also Feldman and Steenbergen 2001), we include measures of individualist and egalitarian value orientations, measured outside the domain of race. In the 1986 NES, we replicate the individualism and egalitarianism scales constructed by Sears, Henry, and Kosterman $(2000,117)$. In 2000, while the six egalitarianism items remain the same, the items available to measure individualism are reduced to two, and our scale is adjusted accordingly. ${ }^{20}$ In both models, we include the crucial variable of anti-black affect (measured with an inverse of the feeling thermometer for blacks), assuming that old-fashioned, straightforward racial antipathy will powerfully shape responses to the symbolic racism items. Finally, and most importantly for our purposes, we include our political sophistication scale to test the cognitive hypotheses that we articulate above.

Table 1 reports the results of our overall symbolic racism models in 1986 and 2000. The results confirm

\footnotetext{
${ }^{20}$ These two items in the 2000 NES are Variables 000620 and 001423, asking respondents whether they believe government should guarantee everyone a good standard of living or let people get ahead on their own, and whether it is more important to be cooperative or self-reliant.
}

both much of the conventional wisdom on symbolic racism and our new hypotheses on political sophistication. In both years, liberals, the better educated, and those living outside the South score lower than do others. In addition, individualism, egalitarianism, and anti-black affect are consistently powerful and work as expected. Clearly, scores on the symbolic racism index are strongly shaped by both racial hostility and general value orientations.

Most importantly for our purposes, low political sophistication emerges as a major predictor of symbolic racism in both years, even after controlling for ideology, individualism, egalitarianism, education, and anti-black affect. It is important to emphasize these controls because the result itself may not be surprising. It is often posited that the politically sophisticated are more liberal (ideology), more schooled in the "proper" responses and exposed to diverse perspectives (education), and/or less likely to be oldfashioned racists (anti-black affect). Any or all of these claims may be true, yet the powerful effect of sophistication we demonstrate here persists even after accounting for these possibilities. Thus we must look deeper for the source of sophistication's effect on symbolic racism, an effect that we argue is rooted in heterogeneous attribution.

If the effect of political sophistication on symbolic racism results from differential causal attributions 
TABle 2 Ordered Probit Models of Symbolic Racism Scale Components: Individual Attributions, ANES 1986 and 2000 (Whites Only)

\begin{tabular}{|c|c|c|c|c|}
\hline \multirow[b]{2}{*}{$\begin{array}{l}\text { Independent } \\
\text { Variables }\end{array}$} & \multicolumn{2}{|c|}{1986} & \multicolumn{2}{|c|}{2000} \\
\hline & $\begin{array}{c}\text { Question } 1 \\
\beta \text { (S.E.) }\end{array}$ & $\begin{array}{c}\text { Question } 2 \\
\beta \text { (S.E.) }\end{array}$ & $\begin{array}{c}\text { Question } 1 \\
\beta \text { (S.E.) }\end{array}$ & $\begin{array}{c}\text { Question } 2 \\
\beta \text { (S.E.) }\end{array}$ \\
\hline Black Interviewer & $.541(.243)^{\star}$ & $.346(.235)$ & $-.187(.189)$ & $.052(.187)$ \\
\hline Female & $-.059(.093)$ & $-.226(.092)^{* *}$ & $-.110(.085)$ & $-.137(.083)^{\star}$ \\
\hline Age & $.006(.003)^{\star}$ & $-.004(.003)$ & $.004(.003)$ & $.005(.003)^{*}$ \\
\hline South & $.374(.103)^{\star * *}$ & $.243(.099)^{\star \star}$ & $.002(.089)$ & $.157(.086)^{\star}$ \\
\hline Income & $-.016(.008)^{\star}$ & $-.026(.008)^{* *}$ & $.009(.011)$ & $.011(.011)$ \\
\hline Church Attendance & $-.019(.030)$ & $.015(.029)$ & $.014(.027)$ & $-.029(.026)$ \\
\hline Education & $-.159(.034)^{\star *}$ & $-.098(.033)^{\star *}$ & $-.142(.032)^{\star *}$ & $-.147(.031)^{\star x}$ \\
\hline Party ID (Dem) & $.012(.023)$ & $.024(.022)$ & $-.025(.024)$ & $.040(.023)^{\star}$ \\
\hline Ideology (Liberal) & $-.085(.041)^{\star}$ & $-.093(.041)^{\star}$ & $-.072(.030)^{\star *}$ & $-.116(.030)^{\star x}$ \\
\hline Individualism & $1.363(.285)^{\star *}$ & $1.884(.281)^{* *}$ & $.370(.135)^{\star *}$ & $.340(.131)^{* x}$ \\
\hline Egalitarianism & $-1.162(.255)^{\star \star}$ & $-1.058(.250)^{\star *}$ & $-1.622(.240)^{* *}$ & $-1.698(.231)^{\star x}$ \\
\hline Anti-Black Affect & $.010(.002)^{\star *}$ & $.008(.002)^{\star *}$ & $.006(.002)^{\star *}$ & $.006(.002)^{* x}$ \\
\hline Political Sophist. & $-.448(.203)^{\star}$ & $-1.060(.202)^{\star \star}$ & $-.344(.186)^{\star}$ & $-.835(.183)^{* x}$ \\
\hline$\mu_{1}=$ & $-2.367(.338)^{\star *}$ & $-2.331(.328)^{\star *}$ & $-3.403(.297)^{\star *}$ & $-3.075(.280)^{\star \star}$ \\
\hline$\mu_{2}=$ & $-1.184(.323)^{\star *}$ & $-1.324(.320)^{\star \star}$ & $-2.380(.280)^{\star *}$ & $-2.048(.269)^{\star x}$ \\
\hline$\mu_{3}=$ & $-.746(.321)^{\star}$ & $-.896(.317)^{\star \star}$ & $-1.925(.277)^{\star \star}$ & $-1.540(.267)^{\star x}$ \\
\hline$\mu_{4}=$ & $.333(.321)$ & $.309(.317)$ & $-.920(.273)^{\star \star}$ & $-.600(.265)^{\star}$ \\
\hline Log Likelihood = & -827.475 & -872.647 & -968.440 & $-1,078.663$ \\
\hline LR $\chi^{2}$ (d.f. $)=$ & $213.77(13)^{* *}$ & $220.51(13)^{* *}$ & $207.57(13)^{* *}$ & $253.28(13)^{* *}$ \\
\hline $\mathrm{N}=$ & 656 & 659 & 785 & 780 \\
\hline
\end{tabular}

Question 1: "Irish, Italians, Jews, and many other minorities overcame prejudice and worked their way up. Blacks should do the same without any special favors."

Question 2: "It's really a matter of some people not trying hard enough; if blacks would only try harder they could be just as well off as whites."

Source: American National Elections Studies, 1986 and 2000.

$* * p<.01$, one-tailed test.

${ }^{*} p<.05$, one-tailed test.

rooted in general cognitive tendencies, this pattern should manifest itself in an analysis of the individual components of the symbolic racism scale. Specifically, sophistication should dramatically decrease the likelihood that individuals will attribute racial disparities to character failings or lack of hard work, while sharply increasing the tendency to ascribe causality to broad social factors. ${ }^{21}$ The models reported in Table 2 explore the first part of this proposition, examining

\footnotetext{
${ }^{21}$ While the analyses might seem a bit redundant, the separate models are necessary to demonstrate that the effect of sophistication on symbolic racism is actually symmetric, as our theory argues. It would, of course, be possible to see the sophistication effect demonstrated in Table 1 if the underlying mechanism strictly worked asymmetrically. That is, if political sophistication were found to be a significant, negative predictor of the individualist scale components, but was unrelated to the structuralist scale components, it is possible (likely) that we would still see a significant, negative effect on the overall scale. This asymmetric effect is not predicted by our theory. Thus, the analyses of scale components are important tests of the underlying theory.
}

the two individual attribution items from the symbolic racism scale in both 1986 and 2000. These models use the same set of independent variables employed for our analysis of the entire scale and described above. Since responses to each individual item range only from 0 (strongly disagree) to 4 (strongly agree), we employ an ordered probit estimation.

The demographic items in these models are mostly a mixed bag, with only southern residence and (especially) education exerting a consistent influence across years and items. Otherwise, as one might expect, the attitudinal variables appear to drive responses. Consistent with the findings of Sniderman and his various colleagues, ideology has a consistent effect, with self-identified liberals tending to shun individualistic attributions. Likewise, orientations toward individualist and egalitarian values have very strong effects in the directions one would expect. Antiblack affect, unsurprisingly, also strongly motivates 
TABLe 3 Ordered Probit Models of Symbolic Racism Scale Components: Structural Attributions, ANES 1986 and 2000 (Whites Only)

\begin{tabular}{|c|c|c|c|c|}
\hline \multirow[b]{2}{*}{$\begin{array}{l}\text { Independent } \\
\text { Variables }\end{array}$} & \multicolumn{2}{|c|}{1986} & \multicolumn{2}{|c|}{2000} \\
\hline & $\begin{array}{c}\text { Question 1 } \\
\text { Estimate (S.E.) }\end{array}$ & $\begin{array}{c}\text { Question } 2 \\
\text { Estimate (S.E.) }\end{array}$ & $\begin{array}{c}\text { Question } 1 \\
\text { Estimate (S.E.) }\end{array}$ & $\begin{array}{c}\text { Question } 2 \\
\text { Estimate (S.E.) }\end{array}$ \\
\hline Black Interviewer & $-.409(.236)^{*}$ & $.560(.236)^{\star \star}$ & $-.100(.190)$ & $.108(.186)$ \\
\hline Female & $-.056(.091)$ & $.037(.091)$ & $.134(.083)$ & $-.009(.083)$ \\
\hline Age & $-.002(.003)$ & $.005(.003)^{\star}$ & $.003(.003)$ & $.005(.003)^{\star}$ \\
\hline South & $-.202(.099)^{\star}$ & $-.265(.098)^{\star *}$ & $-.263(.087)^{\star *}$ & $-.086(.086)$ \\
\hline Income & $-.004(.008)$ & $.002(.008)$ & $-.012(.011)$ & $-.010(.011)$ \\
\hline Church Attendance & $.057(.029)^{\star}$ & $.038(.029)$ & $.006(.026)$ & $.018(.026)$ \\
\hline Education & $.078(.033)^{\star *}$ & $.103(.033)^{\star *}$ & $.032(.031)$ & $.091(.030)^{\star * *}$ \\
\hline Party ID (Dem) & $.004(.022)$ & $-.003(.022)$ & $.027(.023)$ & $.006(.023)$ \\
\hline Ideology (Liberal) & $.100(.040)^{\star *}$ & $.068(.040)^{\star}$ & $.059(.030)^{\star}$ & $.068(.030)^{\star}$ \\
\hline Individualism & $-1.097(.274)^{\star *}$ & $-.722(.274)^{\star *}$ & $-.277(.132)^{\star}$ & $-.204(.132)$ \\
\hline Egalitarianism & $.977(.249)^{\star *}$ & $.594(.247)^{\star \star}$ & $1.406(.231)^{\star *}$ & $2.012(.235)^{* *}$ \\
\hline Anti-Black Affect & $-.011(.002)^{* *}$ & $-.011(.002)^{\star *}$ & $-.008(.002)^{\star *}$ & $-.008(.002)^{* *}$ \\
\hline Political Sophist. & $.462(.199)^{\star *}$ & $.657(.201)^{\star *}$ & $.447(.182)^{\star *}$ & $.326(.183)^{\star}$ \\
\hline$\mu_{1}=$ & $-.804(.316)^{* *}$ & $-.655(.317)^{\star}$ & $.306(.264)$ & $.871(.267)^{\star \star}$ \\
\hline$\mu_{2}=$ & $.418(.315)$ & $.066(.315)$ & $1.275(.266)^{\star *}$ & $1.674(.270)^{* *}$ \\
\hline$\mu_{3}=$ & $1.129(.317)^{* *}$ & $.323(.316)$ & $1.790(.269)^{\star *}$ & $1.946(.271)^{* *}$ \\
\hline$\mu_{4}=$ & $2.229(.331)^{\star *}$ & $1.655(.321)^{\star *}$ & $3.051(.285)^{\star *}$ & $3.209(.284)^{\star *}$ \\
\hline Log Likelihood = & -856.537 & -899.050 & $-1,050.927$ & $-1,068.509$ \\
\hline $\operatorname{LR} \chi^{2}$ (d.f.) $=$ & $142.58(13)^{\star *}$ & $134.06(13)^{\star *}$ & $160.07(13)^{\star \star}$ & $206.71(13)^{\star \star}$ \\
\hline$N=$ & 655 & 660 & 778 & 783 \\
\hline
\end{tabular}

Question 1: "Over the past few years, blacks have gotten less than they deserve."

Question 2: "Generations of slavery and discrimination have created conditions that make it difficult for blacks to work their way out of the lower class."

Source: American National Elections Studies, 1986 and 2000.

${ }^{* *} p<.01$, one-tailed test.

${ }^{*} p<.05$, one-tailed test.

individualistic explanations for black social disadvantage. Most importantly, though, even after controlling for these attitudinal orientations, political sophistication remains a consistent and powerful influence in all four models. This result clearly lends credence to our theory of heterogeneous attribution, suggesting a link between low sophistication and localized, individualistic attributions that goes beyond education, ideology, values, or racial animus.

So far, we have examined individual attributions for black social disadvantage and found strong effects of political sophistication. There is, however, another side of the coin: structuralist attributions. Our theory predicts that political sophistication should exert a strong, though opposite, influence on these items, making individuals more likely to ascribe black misfortune to societal causes. To explore this, we model responses to the two structuralist symbolic racism scale components in both 1986 and 2000. These models are directly comparable to those in Table 2; the independent variables are identical, and again the models are estimated as ordered probits. Here, the dependent variables represent responses to the ideas that blacks have "gotten less than they deserve" and that generations of slavery and racism are to blame for blacks' negative social circumstances. The results are reported in Table 3.

As one would expect, southern residence and education continue to play a strong role in shaping racial attributions. Other demographic items have negligible and/or inconsistent effects. As is the case with individualistic attributions, ideology, individualism, egalitarianism, and anti-black affect all play strong and consistent roles. Once again, however, political sophistication remains a significant predictor of attributions (this time in a positive direction) even after controlling for these other factors. More sophisticated respondents, ceteris paribus, are substantially 
more likely to agree that blacks have been victimized by societal and historical factors beyond their control, a result consistent with the theory of heterogeneous attribution. As the theory predicts, unsophisticated respondents are both more likely to focus on individual loci of causality and less likely to identify social ones.

\section{Individualism Redux?}

A comment about the proper interpretation of individualistic attributions in these findings seems necessary. A critic of our results might argue that "individualism" has always been part of symbolic racism. Indeed, since originally proposed by Sears and Kinder (1971), symbolic racism has been conceived as a blend of anti-black affect and Americans' orientation toward economic individualism. The critic might thus contend that our results for the less sophisticated simply restate the denial of discrimination through individualistic thinking on race issues.

Our response to such a concern is simple. Properly conceived, the "individualism" inherent in the symbolic racism concept is a value orientation-more precisely the value of "economic individualism." The theory underlying symbolic racism states that racist whites view blacks as violating the norm of economic individualism, which, based on the Protestant work ethic, is one of the most enduring values in the American ethos (McCloskey and Zaller 1984). The individualistic attribution bias caused by differences in sophistication, described herein, is not a product of value orientation. Rather, the bias is a cognitive oneindividuals low in sophistication tend only to link proximally located nodes within an associative network, whereas high sophisticates are much more likely to make distal connections as well. Thus, the individualism value orientation and individualist attribution bias are distinct, both theoretically and conceptually.

Moreover, to the greatest extent possible, we have attempted to distinguish these concepts and their effects empirically. The individualism value orientation is measured in traditional fashion, and, notably, it works as others have theorized. The attribution bias caused by political sophistication is also significant here, demonstrating an effect that is conceptually distinct and statistically independent from values. In sum, we strongly believe that the effect of sophistication on explanations for racial inequality and on symbolic racism works precisely as the theory of heterogeneous attribution hypothesizes.

\section{Accounting for Systematic Measurement Error in Symbolic Racism}

It would thus appear, as we have argued, that scores on the symbolic racism index are rooted substantially (though clearly not entirely) in cognitive differences between high and low political sophisticates that shape attributional tendencies for reasons unrelated to racial animus, education, and value orientation. If this is true, any model incorporating symbolic racism as an independent variable will suffer from a classic errors-in-variables problem. To take one specific example, claims about symbolic racism's role in shaping racially relevant policy attitudes may be significantly exaggerated. Rather than providing inferential evidence of a relationship between "covert racism" and policy attitudes, the statistical relationship might be, at least partially, spurious - a product of attributional bias. Our final analysis is devoted to an examination of this proposition. Drawing on items in the 1986 NES, we assess the real influence of symbolic racism on individuals' attitudes toward racially charged policy questions, including preferences in hiring, quotas in education, spending on food stamps, and federal aid to blacks. ${ }^{22}$

Since we have shown that symbolic racism scores are explained partly by differences in political sophistication as well as racial hostility, we employ and recommend Hausman's (1978) simple test for the presence of systematic measurement error when symbolic racism is included as an explanatory variable in regression models. The result is a straightforward errors-in-variables regression model, constructed in the following manner: Let

$$
Y_{i}^{*}=\alpha+\beta X_{i}^{*}+\varepsilon_{i}^{*}
$$

where, $Y_{i}^{*}$ represents the measured values of $Y_{i}, X_{i}^{*}$ represents the measured values of $X_{i}$, and $\varepsilon_{i}^{*}=\varepsilon_{i}-\beta \xi_{i}$, so that $\varepsilon$ is the standard regression disturbance and $\xi_{i}$ represents the errors in measuring $X_{i}{ }^{23}$ To evaluate the

\footnotetext{
${ }^{22}$ These are Variables 860476, 860478, 860330, and 860334, respectively.

${ }^{23}$ The placement of the measurement error associated with the independent variable(s), $\xi_{i}$, in the error term $\varepsilon_{i}^{*}=\varepsilon_{i}-\beta^{*} \xi_{i}$ results from algebraic manipulation. Rewrite the errors-in-variables regression so that $Y_{i}^{*}=Y_{i}+v_{i}$ and $X_{i}^{*}=X_{i}+\xi_{i}$, allowing $v_{i}$ and $\xi_{i}$ to represent the measurement errors associated with the dependent and independent variables respectively:
}

$$
\left(Y_{i}^{*}-v_{i}\right)=\alpha+\beta\left(X_{i}^{*}-\xi_{i}\right)+\varepsilon_{i} .
$$

Rearranging the error components together, we obtain

$$
Y_{i}^{*}=\alpha+\beta X_{i}^{*}+\left(\varepsilon_{i}+v_{i}-\xi_{i}\right)
$$


extent of measurement bias included in $X_{i}^{*}$, regress $X_{i}^{*}$ on an instrumental variable $Z_{i}$ deemed to be related to the theoretical cause of the bias:

$$
X_{i}^{*}=\gamma+\delta Z_{i}+\omega_{i}
$$

In our case, the instrumental variable is extracted from our 1986 model of symbolic racism estimated in Table 1, which controls for the source of the attribution bias by including political sophistication. Incorporating the least squares residuals $\hat{\omega}_{i}$ from the model above into the model of $Y_{i}^{*}$, produces

$$
Y_{i}^{*}=\alpha+\beta \hat{X}_{i}^{*}+\theta \hat{\omega}_{i}+\varepsilon_{i}^{*}
$$

If the resulting estimate, $\theta$, is statistically significant, we can reject the null hypothesis that no systematic measurement error exists; the magnitude of $\theta$ indicates the direction and extent of the measurement bias. Perhaps more importantly, the resulting $\beta$ reflects the true estimate associated with $X$, which in this case is symbolic racism.

Results of these errors-in-variables regressions are presented in Table 4. Here, support for each of the racially relevant policies is modeled as function of interviewer race, the standard demographic items, party identification and ideology, individualism, egalitarianism, anti-black affect, and symbolic racism. To these, we add in the second column $\hat{\omega}$, the residuals derived from estimating symbolic racism as a product of political sophistication. A comparison of the coefficients for symbolic racism in these two models should show the effects of systematic measurement error stemming from political sophistication.

The results of this examination are dramatic. Looking at the predictors of racial policy attitudes, we find strong effects for political ideology, egalitarianism, Southern residence, and anti-black affect, none of which is particularly surprising. ${ }^{24}$ Our primary interest here, though, is not really in modeling policy attitudes per se, but in assessing the modeling error that stems from the relationship between symbolic racism scores and political sophistication. Here, the results

The equation in the text results from considering $\left(\varepsilon_{i}+v_{i}\right)$ as a single "generalized" disturbance, since measurement error in the dependent variable, if normally distributed, will only contribute to the overall error variance of the model. Of course, if $v_{i}$ is not normally distributed or if the $i$ units are correlated, heteroskedasticity will result. See Kmenta $(1997,346-66)$ for further explication. Pindyck and Rubinfeld (1998, 197-98) also present clearly the errors-in-variables correction.

${ }^{24}$ The one exception to many of these general patterns is attitudes toward food stamp spending. It would appear to be a less racially driven issue than any of the others, not surprising since it is the only one that does not specifically reference race. are unmistakable. Without the measurement correction, symbolic racism shows a strong negative association with individuals' willingness to support all of these racial policies. ${ }^{25}$ By contrast, when $\hat{\omega}$ is introduced into the models, symbolic racism in three of the four cases ceases to be a significant negative predictor, and in the case of educational quotas becomes significant in the opposite direction. ${ }^{26}$ Clearly, based on application of Hausman's (1978) test and criteria, assertions about the relationship between symbolic racism and policy attitudes are fraught with potentially substantial error unless political sophistication is taken into account.

\section{Discussion}

Our analysis seeks to shed light on the relationship between political sophistication and American racial attitudes. Rooting our explanation in a theory of heterogeneous attribution, we argue that less sophisticated individuals are more likely than their more sophisticated counterparts to make localized, individual-level causal attributions for sociopolitical phenomena, and hence to blame African Americans themselves for their social plight. It has long been asserted that racism, however defined and operationalized, is particularly strong among the less sophisticated segment of America's white population. Much of the scholarly discussion of racial animosity in America has centered on "new" or "symbolic" or "modern" racism, and it has often been demonstrated that the less educated and/or sophisticated score higher on these rubrics. Indeed, our own results here confirm the general accuracy of this view.

Our findings, however, suggest that much of the relationship between political sophistication and sym-

\footnotetext{
${ }^{25}$ In three of our four cases, symbolic racism is no longer significant after the inclusion of $\hat{\omega}$. The coefficient sign on these statistically insignificant results does not greatly concern us, since, of course, their confidence intervals suggest that the true parameter may rest on either side of zero. The positive and significant coefficient associated with symbolic racism after the inclusion of $\hat{\omega}$ in the "Quotas in Education" model is admittedly puzzling. Yet our difficulty in explaining the coefficient is directly a function of symbolic racism's operational nature. Given symbolic racism's inherent attributional structure and low dimensionality (Tarman and Sears 2005), it is unclear what remains inherent in the measure once the bias is removed.

${ }^{26}$ Importantly, we do not argue that these policy attitudes are unrelated to racial animus. Indeed, anti-black affect is significant in all but the food stamp model. What we are questioning is how much the construct of symbolic racism adds beyond simple anti-black affect in explaining these attitudes, net of sophistication. Our answer, based on these examinations, would be fairly little.
} 
TABle 4 Testing for Systematic Measurement Error in Symbolic Racism's Effect on Whites' Opposition to Policies Designed to Help Blacks, ANES 1986

\begin{tabular}{|c|c|c|c|c|c|c|c|c|}
\hline \multirow{2}{*}{$\begin{array}{l}\text { Independent } \\
\text { Variables } \\
\text { Constant }\end{array}$} & \multicolumn{2}{|c|}{$\begin{array}{l}\text { W/O } \hat{\omega} \quad \text { With } \omega \\
\text { Preference in Hiring }\end{array}$} & \multicolumn{2}{|c|}{$\begin{array}{c}\text { W/O } \hat{\omega} \quad \text { With } \hat{\omega} \\
\text { Quotas in Education }\end{array}$} & \multicolumn{2}{|c|}{ Food Stamps } & \multicolumn{2}{|c|}{ Federal Aid to Blacks } \\
\hline & $\begin{array}{l}1.787^{\star *} \\
(.323)\end{array}$ & $\begin{array}{c}.515^{\star} \\
(.816)\end{array}$ & $\begin{array}{l}3.386^{\star *} \\
(.405)\end{array}$ & $\begin{array}{c}.232 \\
(1.028)\end{array}$ & $\begin{array}{c}.351^{\star} \\
(.218)\end{array}$ & $\begin{array}{c}-.185 \\
(.546)\end{array}$ & $\begin{array}{c}.006 \\
(.170)\end{array}$ & $\begin{array}{c}-.299 \\
(.423)\end{array}$ \\
\hline Black Interviewer & $\begin{array}{l}.161 \\
(.213)\end{array}$ & $\begin{array}{l}.127 \\
(.220)\end{array}$ & $\begin{array}{l}.788^{\star *} \\
(.269)\end{array}$ & $\begin{array}{l}.712^{* *} \\
(.277)\end{array}$ & $\begin{array}{l}-.140 \\
(.143)\end{array}$ & $\begin{array}{l}-.174 \\
(.148)\end{array}$ & $\begin{array}{l}.181^{*} \\
(.111)\end{array}$ & $\begin{array}{l}.120 \\
(.115)\end{array}$ \\
\hline Female & $\begin{array}{l}.117 \\
(.080)\end{array}$ & $\begin{array}{l}.115 \\
(.081)\end{array}$ & $\begin{array}{l}.062 \\
(.102)\end{array}$ & $\begin{array}{l}.031 \\
(.101)\end{array}$ & $\begin{array}{l}.025 \\
(.053)\end{array}$ & $\begin{array}{l}.027 \\
(.053)\end{array}$ & $\begin{array}{l}-.001 \\
(.042)\end{array}$ & $\begin{array}{l}.003 \\
(.042)\end{array}$ \\
\hline Age & $\begin{array}{l}.001 \\
(.003)\end{array}$ & $\begin{array}{l}.003 \\
(.003)\end{array}$ & $\begin{array}{l}-.003 \\
(.003)\end{array}$ & $\begin{array}{l}.001 \\
(.003)\end{array}$ & $\begin{array}{l}-.001 \\
(.002)\end{array}$ & $\begin{array}{l}.001 \\
(.002)\end{array}$ & $\begin{array}{l}.002 \\
(.001)\end{array}$ & $\begin{array}{l}.002 \\
(.001)\end{array}$ \\
\hline South & $\begin{array}{l}.006 \\
(.092)\end{array}$ & $\begin{array}{l}-.126 \\
(.115)\end{array}$ & $\begin{array}{l}-.174 \\
(.117)\end{array}$ & $\begin{array}{l}-.467^{\star *} \\
(.146)\end{array}$ & $\begin{array}{l}-.148^{\star *} \\
(.062)\end{array}$ & $\begin{array}{l}-.199^{* *} \\
(.079)\end{array}$ & $\begin{array}{l}-.157^{\star *} \\
(.048)\end{array}$ & $\begin{array}{l}-.191^{\star *} \\
(.060)\end{array}$ \\
\hline Income & $\begin{array}{c}-.002 \\
(.008)\end{array}$ & $\begin{array}{l}.004 \\
(.008)\end{array}$ & $\begin{array}{r}-.017^{\star} \\
(.010)\end{array}$ & $\begin{array}{l}-.005 \\
(.010)\end{array}$ & $\begin{array}{l}-.018^{\star *} \\
(.005)\end{array}$ & $\begin{array}{l}-.016^{\star *} \\
(.006)\end{array}$ & $\begin{array}{l}-.005 \\
(.004)\end{array}$ & $\begin{array}{l}-.003 \\
(.004)\end{array}$ \\
\hline Education & $\begin{array}{r}-.065^{\star} \\
(.029)\end{array}$ & $\begin{array}{l}.008 \\
(.052)\end{array}$ & $\begin{array}{r}-.083^{\star} \\
(.037)\end{array}$ & $\begin{array}{l}.105 \\
(.066)\end{array}$ & $\begin{array}{l}-.013 \\
(.020)\end{array}$ & $\begin{array}{l}.018 \\
(.036)\end{array}$ & $\begin{array}{l}.006 \\
(.015)\end{array}$ & $\begin{array}{l}.021 \\
(.027)\end{array}$ \\
\hline Party ID (Dem) & $\begin{array}{l}.025 \\
(.021)\end{array}$ & $\begin{array}{l}.023 \\
(.020)\end{array}$ & $\begin{array}{l}.010 \\
(.026)\end{array}$ & $\begin{array}{l}.003 \\
(.026)\end{array}$ & $\begin{array}{l}.053^{* *} \\
(.014)\end{array}$ & $\begin{array}{l}.052^{* *} \\
(.013)\end{array}$ & $\begin{array}{l}.018^{\star} \\
(.011)\end{array}$ & $\begin{array}{l}.017 \\
(.011)\end{array}$ \\
\hline Ideology (Liberal) & $\begin{array}{l}.092^{* *} \\
(.037)\end{array}$ & $\begin{array}{l}.129^{* *} \\
(.041)\end{array}$ & $\begin{array}{r}.094^{*} \\
(.046)\end{array}$ & $\begin{array}{l}.179^{* *} \\
(.053)\end{array}$ & $\begin{array}{l}.068^{\star *} \\
(.024)\end{array}$ & $\begin{array}{l}.052^{\star *} \\
(.014)\end{array}$ & $\begin{array}{l}.059^{* *} \\
(.020)\end{array}$ & $\begin{array}{l}.064^{\star *} \\
(.022)\end{array}$ \\
\hline Individualism & $\begin{array}{l}.010 \\
(.260)\end{array}$ & $\begin{array}{c}-.554 \\
(.408)\end{array}$ & $\begin{array}{l}-.028 \\
(.327)\end{array}$ & $\begin{array}{c}-1.343^{\star *} \\
(.517)\end{array}$ & $\begin{array}{l}-.572^{\star *} \\
(.175)\end{array}$ & $\begin{array}{l}-.844^{\star *} \\
(.280)\end{array}$ & $\begin{array}{l}.123 \\
(.137)\end{array}$ & $\begin{array}{c}-.071 \\
(.214)\end{array}$ \\
\hline Egalitarianism & $\begin{array}{l}.319 \\
(.231)\end{array}$ & $\begin{array}{l}.780^{\star} \\
(.360)\end{array}$ & $\begin{array}{l}.135 \\
(.292)\end{array}$ & $\begin{array}{l}1.253^{\star *} \\
(.454)\end{array}$ & $\begin{array}{l}.225 \\
(.156)\end{array}$ & $\begin{array}{l}.469^{\star} \\
(.242)\end{array}$ & $\begin{array}{l}.519^{* *} \\
(.121)\end{array}$ & $\begin{array}{l}.692^{\star *} \\
(.187)\end{array}$ \\
\hline Anti-Black Affect & $\begin{array}{c}-.003 \\
(.002)\end{array}$ & $\begin{array}{r}-.007^{\star} \\
(.003)\end{array}$ & $\begin{array}{r}-.002^{\star} \\
(.003)\end{array}$ & $\begin{array}{l}-.013^{\star *} \\
(.004)\end{array}$ & $\begin{array}{c}-.001 \\
(.001)\end{array}$ & $\begin{array}{l}-.001 \\
(.002)\end{array}$ & $\begin{array}{l}-.006^{\star *} \\
(.001)\end{array}$ & $\begin{array}{l}-.007^{* *} \\
(.001)\end{array}$ \\
\hline Symbolic Racism & $\begin{array}{c}-1.163^{\star *} \\
(.211)\end{array}$ & $\begin{array}{c}.680 \\
(1.103)\end{array}$ & $\begin{array}{c}-2.061^{\star *} \\
(.266)\end{array}$ & $\begin{array}{c}2.482^{\star} \\
(1.390)\end{array}$ & $\begin{array}{l}-.573^{* *} \\
(.141)\end{array}$ & $\begin{array}{l}.187 \\
(.743)\end{array}$ & $\begin{array}{l}-.683^{* *} \\
(.110)\end{array}$ & $\begin{array}{l}-.215 \\
(.571)\end{array}$ \\
\hline$\hat{\omega}$ & - & $\begin{array}{c}-1.894^{\star} \\
(1.122)\end{array}$ & - & $\begin{array}{c}-4.699^{\star *} \\
(1.416)\end{array}$ & - & $\begin{array}{l}-.784 \\
(.757)\end{array}$ & - & $\begin{array}{l}-.480 \\
(.583)\end{array}$ \\
\hline $\begin{array}{l}\text { Adj. } \mathrm{R}^{2}= \\
\mathrm{N}=\end{array}$ & $\begin{array}{l}.109^{\star *} \\
637\end{array}$ & $\begin{array}{l}.116^{\star *} \\
629\end{array}$ & $\begin{array}{l}.158^{\star *} \\
634\end{array}$ & $\begin{array}{l}.171^{\star *} \\
626\end{array}$ & $\begin{array}{l}.173^{\star *} \\
620\end{array}$ & $\begin{array}{l}.182^{\star \star} \\
612\end{array}$ & $\begin{array}{l}.290^{\star *} \\
634\end{array}$ & $\begin{array}{l}.296^{\star x} \\
626\end{array}$ \\
\hline
\end{tabular}

Entries are Ordinary Least Squares estimates with standard errors in parentheses.

${ }^{* *} p<.01$, one-tailed test.

${ }^{*} p<.05$, one-tailed test

Source: American National Elections Studies, 1986. The policy positions analyzed are based on variables 860476, 860478, 860330, and 860334, respectively.

bolic racism stems not from racial animus, but from differential patterns of attribution that reach well beyond the domain of race. Indeed, our previous research has shown that the same relationship between political sophistication and individual-level attributions that we show here is operative in the much different domain of economic voting as well (Gomez and Wilson 2001, 2003, 2006b). Since much of the traditional symbolic racism scale is based on respondent attributions of causality, the general tendency of less sophisticated individuals to seize upon localized explanations for sociopolitical events can easily be misconstrued as racial hostility.
Symbolic racism's fundamental dependence on cognitive attributions is problematic not only when the construct is used as a dependent variable, but also when it is used as a predictor of other racially charged attitudes. If we do not take into account political sophistication (as previous scholars have not), it appears that symbolic racism significantly shapes individuals' attitudes toward welfare and affirmative action, even after controlling for overt anti-black affect. This suggests the existence of a subtle, covert racial animus driving white Americans' responses to racialized public policies. However, once the symbolic racism construct is purged of systematic measurement 
error arising from different attributional tendencies of people at varying levels of political sophistication, it appears to contribute little beyond ideology, value orientations, and anti-black affect. From this, we may infer that any apparent effects of symbolic racism in the unadjusted policy models are driven by political sophistication and its link to attributional tendencies, a general cognitive relationship that transcends the specific domain of race.

We do not suggest that political sophistication is unrelated to racial hostility, nor that racial hostility is unrelated to policy attitudes. More sophisticated individuals consistently evince lower levels of anti-black affect (as measured by the feeling thermometer) than do the less sophisticated, and this anti-black affect is frequently an important predictor of opposition to racially ameliorative policies. Certainly, the understanding of diverse people and perspectives that typically comes with broad knowledge may be expected to decrease individuals' racial prejudices, and decreased prejudice will obviously make people more open to the ideas of affirmative action, increased welfare spending, etc. Our analysis here, however, suggests that these relationships proceed largely through the fairly direct, observable medium of anti-black affect, a measure seemingly untainted by cognitive attributional biases.

In sum, our work demonstrates that scores on the symbolic racism scale are in large part a function of an individual's propensity to make individualistic or structuralistic attributions. This, in turn, leads us to exaggerate the racial hostility of less sophisticated Americans (and, perhaps, to exaggerate the racial tolerance of the more sophisticated). Once this attributional tendency, rooted in political sophistication, is controlled for, the effects of symbolic racism on policy attitudes greatly dissipate. Clearly, we must appreciate the properties of causal attributions if we are truly to understand the relationship between political sophistication and the "new racism".

\section{Acknowledgments}

The authors would like to thank David Sears, Tom Hansford, James Hardin, Brad Jones, George Krause, and participants at the University of South Carolina's Political Science Research Workshop for their helpful comments over the course of this project. Funding for this research was provided by grants from the University of South Carolina's College of Liberal Arts and the John G. Tower Center for Political Studies at Southern
Methodist University. Please direct all correspondence regarding this manuscript to Professor Wilson.

Manuscript submitted 22 March 2005

Manuscript accepted for publication 9 September 2005

\section{References}

Cacioppo, John T., Richard E. Petty, Jeffrey Feinstein, and W. Blair G. Jarvis. 1996. "Dispositional Differences in Cognitive Motivation: The Life and Times of Individuals Varying in Need for Cognition.” Psychological Bulletin 119 (2): 197-253.

Converse, Philip E. 1964. "The Nature of Belief Systems in Mass Publics." In Ideology and Discontent, ed. David E. Apter. New York: Free Press.

Delli Carpini, Michael X., and Scott Keeter. 1993. "Measuring Political Knowledge: Putting First Things First." American Journal of Political Science 37 (4): 1179-1206.

Delli Carpini, Michael X., and Scott Keeter. 1996. What Americans Know About Politics and Why It Matters. New Haven: Yale University Press.

Feagin, Joe. 1972. "Poverty: We Still Believe that God Helps Those Who Help Themselves.” Psychology Today 6 (2): 101-29.

Feldman, Stanley. 1988. "Structure and Consistency in Public Opinion: The Role of Core Beliefs and Values." American Journal of Political Science 32 (2): 416-40.

Feldman, Stanley, and Marco R. Steenbergen. 2001. "The Humanitarian Foundation of Public Support for Social Welfare." American Journal of Political Science 45 (3): 658-77.

Fiske, Susan T., and Shelley E. Taylor. 1991. Social Cognition, 2nd ed. New York: Random House.

Gilens, Martin. 1996. “'Race Coding' and White Opposition to Welfare.” American Political Science Review 90 (3): 593-604.

Gomez, Brad T., and J. Matthew Wilson. 2001. "Political Sophistication and Economic Voting in the American Electorate: A Theory of Heterogeneous Attribution." American Journal of Political Science 45 (4): 899-914.

Gomez, Brad T., and J. Matthew Wilson. 2003. "Causal Attribution and Economic Voting in American Congressional Elections." Political Research Quarterly 56 (3): 271-82.

Gomez, Brad T., and J. Matthew Wilson. 2006a. The Blame Game: Political Sophistication and Causal Attribution in American Politics. Unpublished book manuscript, Southern Methodist University and University of South Carolina.

Gomez, Brad T., and J. Matthew Wilson. 2006b. "Cognitive Heterogeneity and Economic Voting: A Comparative Analysis of Four Democratic Electorates." American Journal of Political Science 50 (1): 127-45.

Hausman, J. A. 1978. "Specification Tests in Econometrics." Econometrica 46 (2): 403-26.

Heider, Fritz. 1958. The Psychology of Interpersonal Relations. New York: Wiley.

Hilton, Denis J., and Ben R. Slugoski. 1986. "Knowledge-based Causal Attribution: The Abnormal Conditions Focus Model." Psychological Review 93 (1): 75-88.

Hughes, Michael, and Steven Tuch. 2000. "How Beliefs About Poverty Influence Racial Policy." In Racialized Politics: The Debate About Racism in America, eds. David O. Sears, Jim Sidanius, and Lawrence Bobo. Chicago: University of Chicago Press, pp. 165-190. 
Hunt, Matthew O. 1996. "The Individual, Society, or Both? A Comparison of Black, Latino, and White Beliefs About the Causes of Poverty." Social Forces 75 (1): 293-322.

Iyengar, Shanto. 1989. "How Citizens Think About National Issues: A Matter of Responsibility." American Journal of Political Science 33 (4): 878-900.

Jones, Edward E., and Keith E. Davis. 1965. "From Acts to Dispositions: The Attribution Process in Person Perception." In Advances in Experimental Social Psychology, Volume 2, ed. Leonard Berkowitz. New York: Academic Press, pp. 219-66.

Kelley, Harold H. 1967. "Attribution Theory in Social Psychology." In Nebraska Symposium on Motivation, Volume 15, ed. D. Levine. Lincoln: University of Nebraska Press, pp. 192-240.

Kinder, Donald R., and Lynn M. Sanders. 1996. Divided by Color. Chicago: University of Chicago Press.

Kinder, Donald R., and David O. Sears. 1981. "Prejudice and Politics: Symbolic Racism Versus Racial Threats to the Good Life." Journal of Personality and Social Psychology 40 (2): 414-31.

Kluegel, James R. 1990. “Trends in Whites' Explanations of the Black-White Gap in Socioeconomic Status, 1977-1989.” American Sociological Review 55 (4): 512-25.

Kluegel, James R., and Eliot R. Smith. 1986. Beliefs About Inequality: Americans' Views on What Is and What Ought to Be. New York: Aldine de Gruyter.

Kmenta, Jan. 1997. Elements of Econometrics. 2nd ed. Ann Arbor: University of Michigan Press.

Lau, Richard R., and David O. Sears. 1981. "Cognitive Links Between Economic Grievances and Political Responses." Political Behavior 3 (4): 279-302.

Luskin, Robert L. 1987. "Measuring Political Sophistication." American Journal of Political Science 31 (4): 856-99.

McClosky, Herbert. 1964. "Consensus and Ideology in American Politics." American Political Science Review 58 (2): 361-82.

McClosky, Herbert, and John Zaller. 1984. The American Ethos: Public Attitudes Towards Capitalism and Democracy. Cambridge: Harvard University Press.

McGraw, Kathleen M., and Neil Pinney. 1990. "The Effects of General and Domain-Specific Expertise on Political Memory and Judgment Processes." Social Cognition 8 (1): 9-30.

Nesbitt, Richard E., and Lee Ross. 1980. Human Inference: Strategies and Shortcomings of Social Judgment. Englewood Cliffs: Prentice-Hall.

Petty, Richard E., and John T. Cacioppo. 1996. Attitudes and Persuasion: Classic and Contemporary Approaches. Boulder: Westview Press.

Pindyck, Robert S., and Daniel L. Rubinfeld. 1998. Econometric Models and Economic Forecasts (Fourth Edition). Boston: McGraw-Hill.
Prothro, James W., and Charles M. Grigg. 1960. "Fundamental Principles of Democracy: Bases of Agreement and Disagreement." Journal of Politics 22 (2): 276-94.

Sears, David O. 1988. “Symbolic Racism.” In Eliminating Racism: Profiles in Controversy, eds. Phyllis A Katz and Dalmas A. Taylor. New York: Plenum Press.

Sears, David O., P. J. Henry, and Rick Kosterman. 2000. "Egalitarian Values and Contemporary Racial Politics." In Racialized Politics: The Debate About Racism in America, eds. David O. Sears, Jim Sidanius, and Lawrence Bobo. Chicago: University of Chicago Press, pp. 75-117.

Sears, David O., and Donald R. Kinder. 1971. "Racial Tensions and Voting in Los Angeles." In Los Angeles: Viability and Prospects for Metropolitan Leadership, ed. Werner Z. Hirsch. New York: Praeger.

Sniderman, Paul M. 1993. "The New Look in Public Opinion Research.” In Political Science: The State of the Discipline II, ed. Ada W. Finifter. Washington: American Political Science Association, pp. 219-46.

Sniderman, Paul M., Richard A. Brody, and Philip E. Tetlock. 1991. Reasoning and Choice: Explorations in Political Psychology. Cambridge: Cambridge University Press.

Sniderman, Paul M., and Edward G. Carmines. 1997. Reaching Beyond Race. Cambridge: Harvard University Press.

Sniderman, Paul M., Michael Gray Hagen, Philip E. Tetlock, and Henry E. Brady. 1986. "Reasoning Chains: Causal Models of Policy Reasoning in Mass Publics." British Journal of Political Science 16 (4): 405-30.

Sniderman, Paul M., and Michael G. Hagen. 1985. Race and Inequality: A Study in American Values. Chatham: Chatham House.

Sniderman, Paul M., and Thomas Piazza. 1993. The Scar of Race. Cambridge: Belknap Press/Harvard University Press.

Tarman, Christopher, and David O. Sears. 2005. "The Conceptualization and Measurement of Symbolic Racism.” Journal of Politics 67 (3): 731-61.

Tetlock, Philip E. 1995. “Integrative Complexity.” In The Blackwell Encyclopedia of Social Psychology, eds. Antony S. R. Manstead and Miles Hewstone. Oxford: Basil Blackwell, Inc.

Brad T. Gomez is assistant professor of political science, University of South Carolina, Columbia, SC 29208. J. Matthew Wilson is associate professor of political science, Southern Methodist University, Dallas, TX 75275-0117. 